\title{
Improvement of Protein Bioavailability by Solid-State Fermentation of Babassu Mesocarp Flour and Cassava Leaves
}

\author{
E. M. Morales ${ }^{1}\left(\mathbb{D} \cdot\right.$ R. N. Domingos ${ }^{2} \cdot$ D. F. Angelis ${ }^{1}$
}

Received: 8 June 2016/Accepted: 28 October 2016/Published online: 19 November 2016

(C) Springer Science+Business Media Dordrecht 2016

\begin{abstract}
Purpose The worldwide demand of food is continuously increasing along with its selling price. Higher food costs affect the access of poor communities to nutritious food, so become a priority problem to be solved, according to the United Nations. This study provides an alternative and viable contribution to the enrichment of food for poor communities using agricultural byproducts.

Methods Samples of a mixture of cassava leaves and babassu mesocarp fermented in solid-state way with $R h i$ zopus oligosporus were submitted to evaluation of protein quantity and quality, by the comparison of the digestibility before and after the solid-state fermentation. The assessment of essential amino acids, relative nutritional value and protein digestibility-corrected amino acid score (PDCAAS) estimated the quality of the protein.

Results The solid-state fermentation increased by $15.2 \%$ the amount of crude protein and improved quality, resulting in a food with relative nutritional value for $98.18 \%$, equating to the casein (100\%). The PDCAAS of fermented mixture (BMF $+32 \%$ CLF) showed results similar to beans and protein textured soybean (PTS) reported, indicating a good source of amino acids $(0.6037$ to the fermented mixture, 0.6296 for beans and 0.6481 to PTS). The SSF also reduced by $94.18 \%$ the amount of cyanide present
\end{abstract}

E. M. Morales

emorales@rc.unesp.br

1 Department of Biochemistry and Microbiology, Institute of Bioscience, Univ. Estadual Paulista - UNESP, Avenida 24-A, 1515, Bela Vista, Rio Claro, SP 13506-900, Brazil

2 Pro-Rectory of Research, Fundação Universidade do Tocantins, 108 Sul Alameda 11, Lote 3, Centro, Palmas, TO 77123-360, Brazil in the mixture, which is a substance derived from the cassava leaves.

Conclusion By the obtained results, it was observed that the use of SSF in byproducts from agroindustry can produce more nutritious food for humans by the transformation of energetic food in structural food which has a higher amount of proteins.

Keywords Relative nutritional value - Cassava leaves . Babassu mesocarp · Rhizopus oligosporus · PDCAAS . Amino acid

\section{Introduction}

Hunger and food wastage are (nowadays) the two biggest problems that the world faces [1]. According to Gustavsson et al. [2], there are approximately 25,000 deaths per day related to starvation, 18,000 of which are children. On the other hand, about 1.3 billion ton of food is wasted annually. Nutritional deficiencies during childhood affect the child's development and lead to a high infant mortality. Additional effects of malnutrition during this age cause injury in psychomotor development, low educational performance and low productive capacity in adulthood [3, 4].

According to the United Nations [5], the number of undernourished people increased in developing countries by 20 million between the years of 2000 and 2008 . The UN still claim that the malnutrition is directly linked to poverty and social inequalities. This document mentions that, even with the prospect of increased demand for food by $70 \%$ until 2050, there is a slowdown in the "green revolution" in agriculture. However, the first aim proposed by the UN to the millennium is eradicating extreme poverty and 
hunger, since $27 \%$ of the world population still lives in extreme poverty [5].

The use of alternative nutritional sources allows lowincome people have access to a balanced diet, with good amounts of protein and other essential nutrients, without the need for expansion of planted areas [6, 7]. Alternative sources of food should present good sensory characteristics, ease of production and desirable functional and nutritional characteristics [8]. The most foods produced in the world are of the energetic group, whose nutritional quality is directly linked to the supply of energy for the organism. However, the main reason for malnutrition is associated with low protein intake. Thus, the conversion of energetic food into another food with high protein levels can contribute to an improvement in the diet, in relation with protein intake.

Examples of common energetic foods (great amounts of carbohydrates) are corn, wheat, rice, manioc, potatoes and others. Babassu (Orbignya sp.) is an important plant for the economy of the Northeast of Brazil, with an annual production of approximately 20 billion coconuts. About $20 \%$ of the coconut weight corresponds to the mesocarp. Babassu mesocarp is a food widely used in the region, but has only energetic characteristics [9-11], which makes it an important source for use in SSF.

Mesocarp flour is a high-carb and low-protein supply that is used as supplementary food for students of elementary school in some low-income communities from Brazil, especially in the Northeast region [12, 13]. The composition of babassu mesocarp is approximately $14.0 \%$ of water, $64.7 \%$ of total carbohydrates, $2.3 \%$ of protein, $2.8 \%$ of lipids, $1.3 \%$ of ashes and $14.9 \%$ of other compounds [14]. Likewise, other crops rich in carbohydrates from various regions of the world can become a potential substrate for Solid-State Fermentation (SSF) and thereby increase the possibility of dietary protein enrichment.

Africa is the largest producer of cassava (Manihot esculenta Crantz) led by Nigeria accounting for $50.5 \%$ of this production, followed by Asia (33.7\%) and South America (15.2\%). In the same period (2008), Brazil contributed with $11.4 \%$ of world production, corresponding to 26.7 million tons [15]. It is estimated that about $2250 \mathrm{~kg}$ of cassava leaves dry weight are produced per hectare [16]. Although cassava leaves present low digestibility index caused by the large amount of fiber [17], they have high protein, vitamin and mineral concentration but this potential is unexplored [18]. According to Oni et al. [19], cassava leaves present $88.4-90.1 \%$ of moisture, $19.7-24.0 \%$ of crude protein, $6.0-7.3 \%$ of lipids, $6.5-16.1 \%$ of ashes and $54.0-65.7 \%$ of total carbohydrates. The same authors report that $59.6-66.2 \%$ of the total carbohydrates are related to fibers.
Materials of low digestibility may be modified by microbial fermentation making them more suitable for nutrition [20]. Solid-state fermentation is presented as a simple procedures and low infrastructure cost that may be successfully applied in cassava leaves to increase the amount of digestible proteins derived from the mycelial growth on plant fiber [20, 21]. During the fermentation, cyanogenic compounds may be metabolized and at the same time new organoleptic characteristics can be added to the final product $[22,23]$. The possible decrease of antinutrients by fermentation is important, since the leaves present some of them as hydrocyanic acid (113-292 ppm),

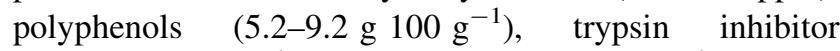

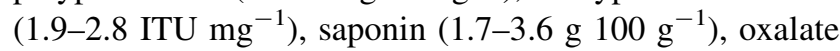

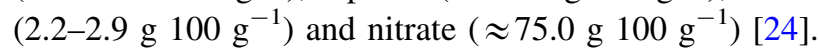

The fungus Rhizopus oligosporus is important economically for the treatment of waste, the production of enzyme and foods (such as tempeh) and inhibition of Gram-positive bacteria [25-27].

The experiences of using $R$. oligosporus suggest that its use is recommended for obtaining food with low fat content and high protein, high antioxidant activity and especially food producing free of toxins [28-30].

The aim of this study was to evaluate the efficiency of SSF with fungus $R$. oligosporus to produce a food with high nutritional value using mesocarp babassu and cassava leaves.

\section{Materials and Methods}

\section{Organism}

Rhizopus microsporus var. oligosporus CCT 3762 (ATCC 22959) was acquired from Tropical Research and Technology Foundation "André Tosello", Campinas-SP, Brazil. Cultures grown in Petri plates at $30 \pm 2{ }^{\circ} \mathrm{C}$ for $72 \mathrm{~h}$ in malt extract agar $5 \%$ were transferred to the $250 \mathrm{~mL}$ Erlenmeyer flasks containing the substrate.

\section{Substrates}

\section{Babassu Mesocarp Flour (BMF)}

The Babassu Mesocarp Flour (BMF) was provided by the Superintendency of Food and Life Quality (PROVIDA), from State Secretariat of Labor and Social Assistance (Secretaria Estadual do Trabalho e de Assistência SocialSETAS) from the municipality of São Miguel do Tocantins-TO, Brazil. The flour was packaged in PVC packs and kept under refrigeration until ready to use. 


\section{Cassava Leaves Flour (CLF)}

Cassava leaves (CL) with 1-2 years old were harvested at the UNESP, Campus Rio Claro, and SP, Brazil. Leaves were sun-dried until to achieve the minimum of $70 \%$ dehydration, according to Silva et al. [31]. After they were triturated in a blender and stored in PVC packs under refrigeration.

\section{Sample Preparation for Fermentation and Substrate Moisture}

To determine the best babassu mesocarp fermentation conditions used in this study, different culture medium (4\% BMF, $4 \%$ of the mixture BMF + CLF (9:1) and 4\% CLF) were mixed in Petri dishes containing agar. The mycelial growth halo of this culture medium was measured after 48 and $96 \mathrm{~h}$ of incubation at $30 \pm 2{ }^{\circ} \mathrm{C}$.

The ideal moisture of the substrate was calculated by the visualization of the growth of mycelia on these different blends (BMF, BMF + CLF and CLF) in different contents of water. Samples with $40,50,55$ and $60 \%$ of moisture were analyzed to verify the proper condition to use during the fermentation process.

\section{Solid-state Fermentation (SSF)}

The solid-state fermentation was performed by the preparation of five sets of five PVC packs (quintuples) containing $30 \mathrm{~g}$ of each sample (substrate) as following information: (1) BMF (pH 5.13); (2) 92\% BMF + 8\% CLF (pH 5.08); (3) 84\% BMF + 16\% CLF (pH 5.07); (4) 68\% $\mathrm{BMF}+32 \%$ CLF (5.03); and (5) CLF (pH 4.86). No corrections on $\mathrm{pH}$ of the substrates were made. The plastic bags were stopped with a cotton stopper to allow the change between the atmospheric gases. The substrates were humidified to $57 \%$ and sterilized at $121{ }^{\circ} \mathrm{C} / 5 \mathrm{~min}(1 \mathrm{~atm})$ followed by the inoculation with $R$. oligosporus $\left(7.59 \times 10^{7}\right.$ spores $/ 30 \mathrm{~g}$ of sample). The packs were maintained at $30 \pm 2{ }^{\circ} \mathrm{C} / 3$ days before all analyses of fermented material.

\section{Analyzed Parameters}

\section{Determination of Total Crude Protein}

Quantification of total nitrogen was carried out (in triplicate) by the Kjeldahl method [32], using the factor 6.25 to convert to total crude protein.

\section{Digestion}

According Akeson and Stahman [33], the digestion was performed in Erlenmeyer flasks $50 \mathrm{~mL}$, adding $1 \mathrm{~g}$ of the tested sample (BMF or BMF + CLF or CLF) and $7.5 \mathrm{~mL}$ of pepsin solution $\left(2 \mathrm{mg} \mathrm{mL}^{-1}\right.$ in $\left.\mathrm{HCl} 0.1 \mathrm{M}\right)$, followed by incubation at $37{ }^{\circ} \mathrm{C}$ during $3 \mathrm{~h}$. The samples were alkalinized with $7.5 \mathrm{~mL}$ of $\mathrm{NaOH} 0.2 \mathrm{M}$, followed by addition of $3.75 \mathrm{~mL}$ of pancreatin solution $\left(2 \mathrm{mg} \mathrm{mL}^{-1}\right.$ in Phosphate Buffer $0.1 \mathrm{M}, \mathrm{pH}$ 8) and incubated at $37{ }^{\circ} \mathrm{C}$ for $24 \mathrm{~h}$. Thereafter, the reaction was stopped with addition of $5 \mathrm{~mL}$ of trichloroacetic acid (TCA) 30\% (w/v) and the volume adjusted to $25 \mathrm{~mL}$ with addition of TCA $5 \%$ (w/v). The samples were centrifuged at $10,000 \mathrm{RPM}$ at $4{ }^{\circ} \mathrm{C}$ for $30 \mathrm{~min}$.

\section{In Vitro Digestibility}

The digestibility of each sample was calculated as the difference between total protein measured by the amount in the precipitate (non digested material) obtained after digestion with pepsin and pancreatin, both determined by the Kjeldahl method [32].

The precipitated material from each sample was submitted to drying in a similar method to the fermented samples $\left(54 \pm 1{ }^{\circ} \mathrm{C}\right)$, in which the amount of protein was quantified. The digestibility of the samples was expressed as a percentage of solubilized proteins.

\section{Determining the Relative Nutritional Value (RNV)}

All the procedures were performed in this study according Ford [34], as following. The assays to calculate the RNV were performed in quadruplicate. The samples were previously degreased using n-hexane in a Soxhlet apparatus [32]. After, the samples and the casein were hydrolyzed under stirring in $4 \mathrm{~mL}$ of pronase Sigma P-5147 $\left(1 \mathrm{mg} \mathrm{mL}^{-1}\right)$ and $40 \mathrm{~mL}$ of sodium glycerophosphate buffer (Sigma G-5422-20 $\mathrm{g} \mathrm{L}^{-1}$ ), adjusted to $\mathrm{pH} 8.0$ (with $\mathrm{NaOH} 0.1 \mathrm{M}$ or $\mathrm{H}_{3} \mathrm{PO}_{4} 0.033 \mathrm{M}$ ) at $48{ }^{\circ} \mathrm{C}$ for $3 \mathrm{~h}$. After hydrolysis, the $\mathrm{pH}$ and the volume of the samples were adjusted to 7.2 and $100 \mathrm{~mL}$ respectively. In the sequence, the samples were sterilized in filter $0.22 \mu \mathrm{m}$ (cold sterilization). After, $2 \mathrm{~mL}$ of the basal medium, $2 \mathrm{~mL}$ of the hydrolyzed sample, $7 \mathrm{~mL}$ of sterilized water and $100 \mu \mathrm{L}$ of Enterococcus zymogenes inoculum were incubated in test tube at $37{ }^{\circ} \mathrm{C}$ for $48 \mathrm{~h}$. Subsequently, the samples were sterilized by autoclaving $\left(121^{\circ} \mathrm{C} / 15 \mathrm{~min}\right)$ and the growth measurements performed by acidimetry. The titrating of each tube was performed with $\mathrm{NaOH} 0.01 \mathrm{M}$ or $\mathrm{H}_{3} \mathrm{PO}_{4} 0.0033 \mathrm{M}$. The value of the total volume used in the test was calculated discounting the volume used for the titration of the blank (carried out with inactive inoculum). The data obtained in the test with $E$. zymogenes are compared with value of standard protein (casein-SIGMA C-7078), considered $100 \%$.

The determination of RNV was taken from the growth of $E$. zymogenes, which occurs according to the quality of the protein present in the sample [35]. The growth response 
is related to the absolute nutritional necessity of essential amino acids (aa) by the microorganism as arginine, glutamic acid, histidine, isoleucine, leucine, methionine, tryptophan, valine and the lysine. Even the lysine not being considered an essential aa to E. zymogenes, its deficiency can impair the growth of the microorganism [34, 35]. As the needs of aa of the microorganism are very similar to human needs (histidine, isoleucine, leucine, lysine, methionine, phenylalanine, threonine, tryptophan and valine), this indirect method of evaluation of RNV presents a good match between these both organisms, because the present enzymes in the human gastrointestinal tract are the same enzymes used in the hydrolysis of the sample.

\section{Essential Amino Acids}

Total amino acids quantification was performed in the laboratory of the Institute of Food Technology, CampinasSP, according to the methods described by White et al. [36] and Hagen et al. [37], excepted the tryptophan that was determined by the method of Spies [38].

\section{Protein Digestibility-Corrected Amino Acid Score (PDCAAS)}

The PDCAAS was obtained by the amino acid profile from samples [39] corrected by the digestibility observed in vitro [35].

From the total crude protein values obtained by the Kjeldahl method, it was possible to estimate the amount of sample $(\mathrm{BMF}+32 \% \mathrm{CLF})$ containing $1 \mathrm{~g}$ of protein. With this value, it was calculated the amount of each essential amino acid for this amount of sample.

The amino acid ratio was individually calculated to His, Thr, Val Met + Cys, Ile, Leu, Phe + Tyr, Lys, and Trp, by dividing the amount of each amino acid of the sample (corresponding to $1 \mathrm{~g}$ of protein) by the reference value of the same amino acid for children 2-5 years, as defined by FAO/WHO [40].

The PDCAAS value of BMF $+32 \%$ CLF was calculated by multiplying the value of the amino acid found in less quantity in the sample by the value of in vitro digestibility of protein [41].

\section{Cyanide Content}

Total cyanide content was evaluated by Center of Tropical Roots and Starches (CERAT_Centro de Raízes e Amidos Tropicais), Botucatu, SP, Brazil.

\section{Statistical Analyzes}

The statistical significance was verified by one-way analyzes of variance (ANOVA) and subsequent application of the $t$ test at SigmaPlot 11.0, comparing the differences between the samples (fermented and unfermented material). Significant differences were understood at $P<0.05$.

\section{Results}

Preliminary experiments were performed to verify if the presence of cassava leaf (CLF) in the substrate containing just babassu mesocarp (BMF) would improve the development of the fungus. For this test, was observed that the inclusion of cassava leaf in the fermentation substrate (BMF) provided more favorable conditions for fungal growth. In the substrate made only with BMF, the fungus growth was virtually zero during the first $48 \mathrm{~h}$. After $96 \mathrm{~h}$ only few hyphae were observed. In the plates with $\mathrm{BMF}+\mathrm{CLF}$ and with CLF, halos sizes was from $4 \mathrm{~cm}$ in diameter after $48 \mathrm{~h}$ and $7 \mathrm{~cm}$ after $96 \mathrm{~h}$. In the plates containing only CLF there was formation of a higher density mycelial.

Furthermore, the relationship between the humidity of the substrate and the fungus growth was also considered. Tests for four different percentages of moisture (45, 50, 55 and $60 \%$ ) were performed and the best growth response was visually observed in tests carried out with $55-60 \%$ humidity.

Considering that the addition of CLF in the substrate with mesocarp promoted a higher growth of the $R$. oligosporus, tests to evaluate the best concentration of CLF to be incorporated into the BMF substrate were performed.

Five sets of different substrates with different quantities of BMF and CLF were performed with the intent to evaluate which mixture would present the ideal results in 3 days. It was found that the addition of $32 \% \mathrm{CLF}$ in $\mathrm{BMF}$ resulted in a significant increase $(P>0.05)$ in crude protein concentration (12.5\%), after fermentation of $72 \mathrm{~h}$ long, while samples containing only the BMF did not show significant increase difference of crude protein (Table 1).

The samples BMF $+8 \% \mathrm{CLF}, \mathrm{BMF}+32 \% \mathrm{CLF}$ and $100 \%$ CLF that showed significant results $(p<0.05)$ after fermentation were submitted to biological assay for estimating the Relative Nutritional Value (RNV) of their proteins. The digestibility and RNV results before and after fermentation, presented in Table 2, indicated that when incorporated $32 \%$ of CLF in the BMF there was only improvement in nutritional quality (RNV) when the mixture was submitted to the solid-state fermentation process (from 19.40 to 98.67 ). The digestibility percentual of the fermented mixture was $77.4 \%$. The RNV value post-fermentation was very similar to the values obtained to casein, which is a complete protein used as standard.

Table 3 shows the total and digestible essential amino acid present in the unfermented BMF (used as 
Table 1 Crude protein quantity before and after fermentation by Rhizopus oligosporus and the relative improvement of crude protein

\begin{tabular}{lcccc}
\hline \multicolumn{5}{l}{ Crude protein $(\%)$} \\
\cline { 2 - 5 } & Before fermentation & After fermentation & Improvement \% & $P$ \\
\hline BMF & $1.53 \pm 0.156$ & $1.75 \pm 0.158$ & 14.38 & 0.301 \\
BMF + 8\% CLF & $3.38 \pm 0.146$ & $3.82 \pm 0.149$ & 13.02 & 0.058 \\
BMF + 16\% CLF & $5.86 \pm 0.399$ & $6.07 \pm 0.335$ & 3.58 & 0.645 \\
BMF + 32\% CLF & $9.74 \pm 0.277$ & $11.22 \pm 0.184$ & 15.20 & $0.005^{*}$ \\
CLF & $26.93 \pm 0.284$ & $29.85 \pm 0.179$ & 10.84 & $<0.001^{*}$ \\
\hline
\end{tabular}

* Results for $P<0.05$ presents significance between the samples $(\alpha=0.05)$ supplementary foods in low-income communities) and in the fermented mixture of BMF $+32 \%$ CLF. The fermented mixture of BMF $+32 \%$ CLF shows high amounts of essential amino acids when compared to the unfermented BMF (Table 3). In this table it was also possible to observe that the incorporation of $32 \%$ of the CLF in BMF increased significantly the values of the essential amino acids in the mixture, except tryptophan.

The necessary amounts of each essential amino acid for a balanced diet [42] and the results obtained are listed in Tables 3 and 4 . The comparison between the data present in both tables become possible to observe that a daily intake of $100 \mathrm{~g}$ of mixture $\mathrm{BMF}+32 \% \mathrm{CLF}$ fermented can supply a good daily requirements of essential amino acids, as recommended by WHO [42], mainly during childhood (Table 4).

The PCDAAS was presented in Table 5.

During the solid-state fermentation process a decrease of $94.18 \%$ (from 10.14 to $0.59 \mathrm{mg} \mathrm{kg}^{-1}$ ) in cyanide concentration was also observed.

\section{Discussion}

Countries whose economy is based in agriculture end up generating large amounts of agricultural waste, which can be used in bioprocesses to obtaining nutritional higher value products $[43,44]$. The solid-state fermentation (SSF), which is a biotechnological process where microorganisms grow on solid matrix and act as a processing agent, also is a promising method for the use of agricultural residues in food production with more nutricional value [45]. The high nutricional value of the fermented material is related to both components: from waste used (substrate) and the proteins present in the fermenter microorganism, since according Sargantanis et al. [46], 27.58\% by weight of $R$. oligosporus cells are constituted of crude protein.

Associating the need to minimize environmental impacts caused by the disposal of agricultural waste with the potential usage of these residues in food production, the application of SSF can be an effective technique to increase the nutritional value of protein, vitamins, phenolic contents, flavonoids, lipids (unsaturated fatty acids) and other important compounds for foods made from such waste, which characterize in an important strategy for solving problems related to the limitation and wastage of the food $[47,48]$.

The results of this study showed that the presence of CLF in BMF exerted a favorable condition in the growth of fungi. This was probably due to the presence of protein compounds in the cassava leaves, which are essential nutrients for the metabolism and growth of fungi. Campos et al. [47] obtained similar results by SSF when used cashew peduncle bagasse. The authors reported a value of $20.3 \%$ of protein post fermentation, which corresponded a 3 times higher increase of that the reported in the beginning
Table 2 Relative nutritional value (RNV) calculated by Enterococcus zymogenes growth in samples of the BMF and CLF before and after fermentation compared with standard protein casein

\begin{tabular}{llcc}
\hline Samples & RNV $(\%)^{\mathrm{a}}$ & Digestibility (\%) & Real RNV (\%) \\
\hline Casein (Sigma C-7078) & 100.00 & 100.00 & 100.00 \\
BMF + 8\% CLF & $23.26 \pm 4.13$ & 66.9 & 15.56 \\
BMF + 8\% CLF-fermented & $29.98 \pm 1.45$ & 64.5 & 19.34 \\
BMF + 32\% CLF & $23.46 \pm 1.39$ & 82.7 & 19.40 \\
BMF + 32\% CLF-fermented* & $127.48 \pm 3.08$ & 77.4 & 98.67 \\
CLF & $81.00 \pm 1.02$ & 75.2 & 60.91 \\
CLF-fermented & $38.06 \pm 1.43$ & 87.3 & 33.23 \\
\hline
\end{tabular}

a Calculated before the application of samples' digestibility (in vitro)

* Results for $P<0.05$ presents significance between the samples $(\alpha=0.05)$ 
Table 3 Improvement of essential amino acid by the addiction of cassava leaves and solid-state fermentation by Rhizopus oligosporus

\begin{tabular}{|c|c|c|c|c|c|}
\hline \multirow[t]{2}{*}{ Essential amino acids } & \multicolumn{2}{|c|}{ BMF-unfermented (mg $\left.100 \mathrm{~g}^{-1}\right)$} & \multicolumn{2}{|c|}{$\mathrm{BMF}+32 \% \mathrm{CLF}-$ fermented $\left(\mathrm{mg} 100 \mathrm{~g}^{-1}\right)$} & \multirow[t]{2}{*}{ Improvement $(\%)$} \\
\hline & Total & Applied digestibility $^{\mathrm{a}}$ & Total & Applied digestibility ${ }^{\mathrm{b}}$ & \\
\hline His & 40.00 & 25.45 & 240.00 & 185.76 & 729.83 \\
\hline Thr & 70.00 & 44.54 & 630.00 & 487.61 & 1094.75 \\
\hline Val & 70.00 & 44.54 & 680.00 & 526.31 & 1181.63 \\
\hline Met + Cys & 0.11 & 0.07 & 220.00 & 170.28 & 243276.78 \\
\hline Ile & 50.00 & 31.82 & 540.00 & 417.95 & 1313.70 \\
\hline Leu & 110.00 & 69.99 & 930.00 & 719.81 & 1028.40 \\
\hline Phe + Tyr & 90.00 & 57.27 & 1220.00 & 944.26 & 1648.88 \\
\hline Lys & 80.00 & 50.90 & 550.00 & 425.69 & 836.26 \\
\hline Trp & ND & 0.00 & ND & 0.00 & 0.00 \\
\hline
\end{tabular}

ND Not detected, His histidine, Thr threonine, Val valine, Met methionine, Cys cysteine, Ile isoleucine, Leu leucine, Phe phenylalanine, Tyr tyrosine, Lys lysine, Trp tryptophan

${ }^{a}$ Digestibility applied by $63.63 \%$ according to REIS [60]

b Digestibility applied by $77.4 \%$ according Table 2

Table 4 Daily requirement for essential amino acids recommended by WHO calculated from the average body weight by age and supply rate of the recommended daily amount of essential amino acids

\begin{tabular}{|c|c|c|c|c|c|c|c|c|c|c|c|c|}
\hline \multirow[t]{2}{*}{ Amino acids } & \multicolumn{6}{|c|}{ Necessity by age $\left(\mathrm{mg} \mathrm{day}^{-1}\right)^{\mathrm{a}}$} & \multicolumn{6}{|c|}{ Supply rate by age $(\%)^{\mathrm{b}}$} \\
\hline & 0.5 & $1-2$ & $3-10$ & $11-14$ & $15-18$ & $>18$ & 0.5 & $1-2$ & $3-10$ & $11-14$ & $15-18$ & $>18$ \\
\hline His & 165.00 & 163.50 & 255.60 & 546.60 & 675.95 & 700.00 & 112.58 & 113.61 & 72.67 & 33.98 & 27.48 & 26.54 \\
\hline Thr & 255.00 & 250.70 & 383.40 & 819.90 & 1044.65 & 1050.00 & 191.22 & 194.50 & 127.18 & 59.47 & 46.68 & 46.44 \\
\hline Val & 367.50 & 392.40 & 617.70 & 1320.95 & 1720.60 & 1820.00 & 143.21 & 134.13 & 85.20 & 39.84 & 30.59 & 28.92 \\
\hline Met + Cys & 232.50 & 239.80 & 383.40 & 774.35 & 983.20 & 1050.00 & 73.24 & 71.01 & 44.41 & 21.99 & 17.32 & 16.22 \\
\hline Ile & 270.00 & 294.30 & 489.90 & 1002.10 & 1290.45 & 1400.00 & 154.80 & 142.02 & 85.31 & 41.71 & 32.39 & 29.85 \\
\hline Leu & 547.50 & 588.60 & 937.20 & 2004.20 & 2580.90 & 2730.00 & 131.47 & 122.29 & 76.80 & 35.91 & 27.89 & 26.37 \\
\hline Phe + Tyr & 442.50 & 436.00 & 639.00 & 1366.50 & 1720.60 & 1750.00 & 213.39 & 216.57 & 147.77 & 69.10 & 54.88 & 53.96 \\
\hline Lys & 480.00 & 490.50 & 745.50 & 1594.25 & 2027.85 & 2100.00 & 88.69 & 86.79 & 57.10 & 26.70 & 20.99 & 20.27 \\
\hline Trp & 71.25 & 69.76 & 102.24 & 218.64 & 276.53 & 280.00 & 0.00 & 0.00 & 0.00 & 0.00 & 0.00 & 0.00 \\
\hline
\end{tabular}

His Histidine, Thr threonine, Val valine, Met methionine, Cys cysteine, Ile isoleucine, Leu leucine, Phe phenylalanine, Tyr tyrosine, Lys lysine, Trp tryptophan

a Adapted from WHO [52]

${ }^{\mathrm{b}}$ Percentage of necessity supplied by the consumption of $100 \mathrm{~g}$ of BMF $+32 \%$ CLF fermented by Rhizopus oligosporus

of the fermentation. The data of Domingos [12] also point to the enrichment of $\mathrm{BM}$ by rice bran, whose inclusion of the rice bran increased the protein concentration of the medium, providing greater development of the fungus.

However, the data obtained for different concentrations of CLF added to the mixtures studied showed an increase in $15.2 \%$ (BMF $+32 \%$ CLF) protein levels after 3 days of fermentation. These results indicate a higher efficiency of incorporation of protein per CLF than by rice bran used by Domingos [12]. According to the results of this author using the same fungus $R$. oligosporus for SSF, there was an increase in the amount of protein after 6 days from the start of the fermentation process, while in our study it was necessary only 3 days to increase the same protein amount. Munhoz [49] observed an increase of $151.6 \%$ protein to sugar cane bagasse fermented by filamentous fungus, after 45 days. The study of Darwish et al. [50] indicates a sharp increase in the amount in $75 \%$ protein level after 7 days and $175 \%$ after 21 days of SSF, when the maize stalks was used as a substrate and having Pleurotus ostreatus as fermenting agent. All these data corroborate the data from this study, demonstrating the efficient use of microorganisms to incorporate proteins in vegetable residues.

By the amount of total protein obtained in this study, it was observed that the inclusion of $32 \%$ of CLF in BMF induced, after the SSF process, a greater increase of protein 
Table 5 Protein digestibility-corrected amino acid scores (PDCAAS), Babassu Mesocarp Flour $+32 \%$ Cassava Leaves Flour, casein standard and daily necessity in $\mathrm{mg}$ of amino acid/g of protein for children of 2-5 years old

\begin{tabular}{|c|c|c|c|c|c|}
\hline \multirow{2}{*}{$\begin{array}{l}\text { Essential } \\
\text { amino acids }\end{array}$} & \multirow{2}{*}{$\begin{array}{l}\mathrm{BMF}+32 \% \mathrm{CLF} \\
\mathrm{mg} \mathrm{aa} / \mathrm{g} \text { protein }\end{array}$} & \multirow{2}{*}{$\begin{array}{l}\text { Casein } \mathrm{mg} \\
\text { aa/g protein }\end{array}$} & \multicolumn{2}{|l|}{ Amino acid ratio } & \multirow{2}{*}{$\begin{array}{l}\text { Standard FAO/ } \\
\text { WHO 2-5 years }\end{array}$} \\
\hline & & & $\mathrm{BMF}+32 \% \mathrm{CLF}^{\mathrm{a}}$ & Casein & \\
\hline His & 21.4 & 18.99 & 1.13 & 1.00 & 19 \\
\hline Thr & 56.2 & 43.22 & 1.65 & 1.27 & 34 \\
\hline Val & 60.6 & 54.95 & 1.73 & 1.57 & 35 \\
\hline Met + Cys & 19.6 & 30.14 & 0.78 & 1.21 & 25 \\
\hline Ile & 48.1 & 46.91 & 1.47 & 1.68 & 28 \\
\hline Leu & 82.9 & 93.05 & 1.26 & 1.41 & 66 \\
\hline Phe + Tyr & 108.7 & 109.71 & 1.73 & 1.74 & 63 \\
\hline Lys & 49.0 & 78.66 & 0.85 & 1.36 & 58 \\
\hline Trp & ND & ND & ND & ND & 11 \\
\hline PDCAAS & - & - & 0.6037 & 1.0000 & - \\
\hline
\end{tabular}

ND Not detected; BMF Babassu Mesocarp Flour; CLF Cassava Leaves Flour; Data of casein according to Pires et al. [41]; Standard protein 2-5 years, according FAO/WHO (1985); His (histidine); Thr threonine, Val valine, Met methionine, Cys cysteine, Ile isoleucine, Leu leucine, Phe phenylalanine, Tyr tyrosine, Lys lysine, Trp tryptophan

${ }^{a}$ True protein digestibility obtained in vitro -0.774 (77.4\%)

in the mixture. This increase was, according to the descriptions of Campos et al. [47], probably due to bioconversion (by fungicidal activity) of the inorganic nitrogen of the substrate (in this case cassava leaf) into organic nitrogen in the mixture. The data of the present study corroborate with those obtained by Campos et al. [47] and Darwish et al. [50], in experiments carried out with cashew peduncle bagasse and maize stalk, respectively.

About the real quality of the protein, Tavano et al. [35], by using the Relative Nutritional Value (RNV) technique to evaluate the nutritional quality of protein by the growth of E. zymogenes, could distinguish the different nutritional aspects of protein fractions of chickpea beans. The results, expressed in Table 2, show that the fermentation increased protein profile of the substrate, as can be observed in the sample BMF $+32 \%$ CLF and conferred a significant RNV increase (about 5 times) in this substrate when it was compared to the same unfermented sample. The obtained value was similar to standard casein (Sigma C-7078, a protein whose RNV pattern is considered $100 \%$ ).

The analysis of the amino acids results indicates the improvement in quantity and quality in fermented sample, suggesting that the action of $R$. oligosporus increased significantly the profile of amino acids available except for tryptophan. These results corroborate the data obtained by Suhet and Fioreze [51], on fermented pineapple wastes by $R$. oligosporus that showed best result in incorporating amino acids except for tryptophan as well.

The amount of some essential amino acids supplied by the consumption of $100 \mathrm{~g}$ of the studied material reaches higher values than those recommended by the WHO [52], mainly to the demand for children of preschool age. For adults, the use of fermented mixture (BMF $+32 \%$ CLF-fermented) may increase about $30 \%$ the supply of essential amino acids and provide to consumers a healthier diet [53].

The PCDAAS was obtained by the amino acid profile from samples [39] corrected by the digestibility observed in vitro value [35]. The PDCAAS value registered for the BMF $+32 \%$ CLF was 0.6037 and the digestibility of this mixture was $77.4 \%$, results similar to those described by Pires et al. [41] for beans (PDCAAS $=0.6296$ and digestibility $=78.7 \%$ ) and protein texturized soybean (soybean PTS $=$ PDCAAS $=0.6481$ and digestibility $=86.41 \%$ ). The PDCAAS value of the mixture was higher than that found for corn (PDCAAS $=0.3707$ ), wheat $($ PDCAAS $=0.4025)$ and soybeans $($ PDCAAS $=0.5382)$, described by the same authors. These results show that solidstate fermentation carried out on the mixture of BMF $+32 \%$ CLF led to increased levels of amino acids and better digestibility of the final product, comparable to levels found in grains which are recognized as important sources of proteins, used in basic food (beans and soy).

Since the nineteenth century, there are reports of poisoning and death arising from ingestion of cassava, due to the presence of cyanogenic glycosides. The acidic stomach $\mathrm{pH}$ turns it into hydrocyanic acid, a volatile compound highly toxic to animals, including man [54]. An unfavorable aspect of the consumption of raw CL is the high concentration of these glycosides. However, processes such as fermentation and cooking reduce significantly the cyanide content of this material [55-57]. 
The data show that the dehydrated CLF, used in this work, presented initially $29.5 \mathrm{mg} \mathrm{kg}^{-1}$ of cyanide, which would make unfeasible consumption. The BMF, in natura, showed a concentration of $1.02 \mathrm{mg} \mathrm{kg}^{-1}$, a value within the acceptable limits of consumption. A mixture of $\mathrm{BMF}+32 \% \mathrm{CLF}$, before fermentation, showed intermediate values recorded for the 2 raw materials used $\left(10.13 \mathrm{mg} \mathrm{kg}^{-1}\right)$. The toxic potential of the extracted HCN cassava was quantitated for the LD50 (lethal dose for the occurrence of 50\%) in mice for $35 \mathrm{mg} \mathrm{kg}^{-1}$ (body weight), while HCN LD50 accepted by the WHO is $10 \mathrm{mg} \mathrm{kg}^{-1}$ [58]. The same author states that the cyanide consumption in amounts lower than lethal dose allows a detoxification mechanism to convert the cyanide in thiocyanate, a nontoxic substance that can be eliminate through urination.

After fermentation, the sample presented values within the limit of edible ingestion according the legislation $\left(0.59 \mathrm{mg} \mathrm{kg}^{-1}\right)$, suggesting the possibility of its use in dietary supplementation. These data about the cyanide reduction prove the effectiveness of the combination of heat treatment (sterilization process) followed by fermentation to reduce cyanide to allowed levels for the human consumption, according to Brazilian food legislation that establishes the maximum concentration of hydrocyanic acid equivalent to $4.0 \mathrm{mg} \mathrm{kg}^{-1}$ of product [53].

Studies by Helbig et al. [59] showed that the concentration of hydrocyanic acid in food supplements (multimixtures) that receive CLF not reached levels hazardous to human health. The authors added only 5\% of CLF to not raise the limit of the cyanide content in the multimixture. However, our results demonstrated that the fermentation process increased the protein content of the final product, using $32 \%$ of CLF, without increasing toxicity of produced food.

\section{Conclusions}

The solid-state fermentation of BMF mixture supplemented with $32 \%$ of CLF (w/w) promoted an increase of the essential amino acids levels, leading to a gain in total crude protein concentration of the final product.

The fermentation efficiency to increase Relative Nutritional Value (RNV) of protein and to decrease of cyanide levels in the mixture fermented by $R$. oligosporus indicates that this mixture is a potential food to be used in human diet.

The production of food from inexpensive sources can be an interesting strategy to achieve food security and improved nutrition and promote sustainable agriculture. This kind of food can be obtained using byproducts from agriculture, as CLF, to generate more sources of rich protein food.
In this study, the results showed that the inclusion of $32 \%$ of CLF in the BMF mixture led to significant increases in protein levels after the process of solid-state fermentation that raised the essential amino acid levels of the tested mixture.

Essential amino acid levels observed for the fermented mixture (BMF $+32 \%$ CLF), exceeded the amounts recorded for corn, wheat and soybeans and became similar to the levels found in beans and textured soy protein besides the decrease in the levels of cyanide in the mixture to acceptable values for consumption.

Based on the results obtained in this work, it can be inferred that the use of a fermented mixture containing $\mathrm{BMF}+32 \% \mathrm{CLF}$ can improve nutritional conditions and therefore be successfully applied as a food supplement in communities with limited access to protein food.

Acknowledgements This work was supported by the Coordenação de Aperfeiçoamento de Pessoal de Nível Superior (CAPES), Brazil.

\section{Compliance with Ethical Standard}

Conflict of interest The authors declare that there are no conflicts of interest.

\section{References}

1. Behnassi, M., Draggan, S., Yaya, S.: Global Food Insecurity: Rethinking Agricultural and Rural Development Paradigm and Policy. Springer, Berlin (2011)

2. Gustavsson, J., Cederberg, C., Sonesson, U., et al.: Global Food Losses and Food Waste. Food and Agriculture Organization of the United Nations, Rome (2011)

3. Black, R.E., Allen, L.H., Bhutta, Z.A., et al.: Maternal and child undernutrition: global and regional exposures and health consequences. Lancet 371, 243-260 (2008)

4. Victora, C.G., Adair, L., Fall, C., et al.: Maternal and child undernutrition: consequences for adult health and human capital. Lancet 371, 302 (2008)

5. UN NU: Painel de Alto Nível do Secretário Geral das Nações Unidas sobre Sustentabilidade Global. New York (2012)

6. Martins, C., Farias, R.: Produção De Alimentos X Desperdício: Tipos, Causas E Como Reduzir Perdas Na Produção Agrícola. Rev. FZVA 9, 20-32 (2002)

7. Cintra, V.M., Vasconcelos, E.T.A., Pereira, I.D.F., Guerra, I.C.O., Marques, A.A., Conceição, M.L., Barros, J.C.: Farinha de banana e de albedo: Opções de enriquecimento alimentar para comunidades carentes. In: IX Encontro Extensão da UFPB, pp. 1-6 (2007)

8. Costa, D.P.S., Romanelli, P.F., Trabuco, E.: Aproveitamento de vísceras não comestíveis de aves para elaboração de farinha de carne. Food Sci. Technol. 28(3), 746-752 (2008)

9. Ferreira, M.E.M.: Modelos Log-normal e Markoviano para estudo da evolução de abundância em uma floresta de babaçu. UFSC - Universidade Federal de Santa Catarina, Florianópolis, SC (1999)

10. Frazão, J.M.F.: Alternativas econômicas para agricultura familiar assentadas em áreas de ecossistemas de babaçuais. Relatório técnico Gov do Estado do Maranhão, São Luis (2001) 
11. Soler, M., Vitali, A., Muto, E.: Babassu nut breaking technique. Food. Sci. Technol. 27, 717-722 (2007). doi:10.1590/S010120612007000400007

12. Domingos, R. N.: Fermentação da farinha do mesocarpo do coco do babaçu (Orbignya sp.), pela ação de Rhizopus microsporus var. oligosporus. Tese (Doutorado) Universidade Estadual Paulista, Instituto de Biociências de Rio Claro, São Paulo (2003)

13. Souza, M.G., Vieira, E.C., Oliveira, P.V.: Determinação de As, $\mathrm{Cd}$ e $\mathrm{Pb}$ em amêndoas e mesocarpo de babaçu, sapucaia, xixá e castanha-do-pará por espectrometria de absorção atômica. Quim. Nova 32, 1442-1446 (2009)

14. Baruque Filho, E.A., Baruque, M.D.G., Freire, D.M., Sant'Anna, G.L.: Ethanol from babassu coconut starch. Technical and economical aspects. Appl. Biochem. Biotechnol. 70-72, 877-886 (1998). doi:10.1007/BF02920198

15. Groxko, M.: Aspectos econômicos da mandioca. Análise da Conjuntura Agropecuária - Safra 2011/2012. Secretaria da Agricultura e Abastecimento, Departamento de Economia Rural, Estado do Paraná, Brazil, p. 14 (2001)

16. Cereda, M.P.: Manejo, uso e tratamento de subprodutos da industrialização da mandioca. Fundação Cargill, Brasília - DF, vol. 4, p. 320 (2001)

17. Oke, O.L.: Problems in the use of cassava as animal feed. Animal Feed Sci. Technol. 3, 345-380 (1978)

18. Agostini, M.R.: Produção e utilização de farinha de mandioca comum en-riquecida com adição das própria folhas desidratadas para consumo alimentar. Universidade Estadual Paulista "Julio de Mesquita Filho" (2006)

19. Oni, A.O., Onwuka, C.F.I., Arigbede, O.M., et al.: Chemical composition and nutritive value of four varieties of cassava leaves grown in South-Western Nigeria. J. Animal Physiol. Animal Nutr. (Berl.) 95, 583-590 (2011). doi:10.1111/j.14390396.2010.01086.x

20. Serzedello, A.: Aspectos históricos do uso de microrganismos na alimentação. An. do Simpósio Recur. Genéticos para América Lat. e Caribe (1999)

21. Woiciechowski, A.: Bioconversão de Hidrolisado Hemicelulósico de Pinus taeda, obtido pelo processo de explosão a vapor, na produção de ácido $1(+)$ lático pelo fungo Rhizopus oryzae. Universidade Federal do Paraná-UFPR (1997)

22. Caplice, E., Fitzgerald, G.F.: Food fermentations: role of microorganisms in food production and preservation. Int. J. Food Microbiol. 50, 131-149 (1999)

23. Kodama, C., Miranda, P., Barbosa, M., et al.: Análise da diversidade bacteriana endofítica por DHPLC durante o processo de fermentação da mandioca. In: An. do $54^{\circ}$ Congr. Bras. Genética. Salvador, p. 203 (2008)

24. Wobeto, C., Corrêa, A.D., de Abreu, C.M.P., et al.: Antinutrients in the cassava (Manihot esculenta Crantz) leaf powder at three ages of the plant. Food. Sci. Technol. 27, 108-112 (2007)

25. Tavares, S.G., Kiyan, C.: Avaliação da qualidade nutricional da proteína da farinha tempeh, produto fermentado, obtido a partir da soja. Aliment. Nutr. 13, 23-33 (2002)

26. Yamada, O., Sakamoto, K., Tominaga, M., et al.: Cloning and heterologous expression of the antibiotic peptide (ABP) genes from Rhizopus oligosporus NBRC 8631. Biosci. Biotechnol. Biochem. 69, 477-482 (2005)

27. Ozsoy, H.D., Kumbur, H., Saha, B., van Leeuwen, J.H.: Use of Rhizopus oligosporus produced from food processing wastewater as a biosorbent for $\mathrm{Cu}$ (II) ions removal from the aqueous solutions. Bioresour. Technol. 99, 4943-4948 (2008). doi:10.1016/j. biortech.2007.09.017

28. Gumbira-Sa'id, E., Doelle, H.W., Greenfield, P.F., Mitchell, D.A.: Protein enrichment of sago starch by solid-state fermentation with Rhizopus spp. World J. Microbiol. Biotechnol. 7, 419-427 (1991)
29. Nout, M.J.R., Kiers, J.L.: Tempe fermentation, innovation and functionality: update into the third millenium. J. Appl. Microbiol. 98, 789-805 (2005). doi:10.1111/j.1365-2672.2004.02471.x

30. Chang, C.T., Hsu, C.K., Chou, S.T., et al.: Effect of fermentation time on the antioxidant activities of tempeh prepared from fermented soybean using Rhizopus oligosporus. Int. J. Food Sci. Technol. 44, 799-806 (2009). doi:10.1111/j.1365-2621.2009. 01907.x

31. Silva, H.O., Fonseca, R.A., Guedes Filho, R.D.S.: Características Produtivas e Digestibilidade da Farinha de Folhas de Mandioca em Dietas de Frangos de Corte com e sem Adição de Enzimas. Rev. Bras. Zootec. 29(3), 823-829 (2000). doi:10.1590/S151635982000000300026

32. Cunniff, P.: Official Methods of Analysis of AOAC International, 16th edn. AOAC International, Gaithersburg, MD (1995)

33. Akeson, W.R., Stahmann, M.A.: A pepsin pancreatin digest index of protein quality evaluation. J. Nutr. 83, 257-261 (1964)

34. Ford, J.E.: A microbiological method for assessing the nutritional value of proteins. Br. J. Nutr. 16, 409-425 (1962)

35. Tavano, O.L., da Silva Júnior, S.I., Demonte, A., Neves, V.A.: Nutritional evaluation of chickpea protein: microbiological and chemical methods. Aliment Nutr. 15, 17-22 (2004)

36. White, J.A., Fry, J.C., Hart, R.J.: An evaluation of the waters Pico tag system for the amino acid analysis of food materials. J. Autom. Chem. 8, 170-177 (1986)

37. Hagen, S.R., Frost, B., Augustin, J.: Precolumn phenylisothiocyanate derivatization and liquid chromatography of amino acids in food. J. Assoc. Off. Anal. Chem. 72, 912-916 (1988)

38. Spies, J.R.: Determination of tryptophan in proteins. Anal. Chem. 39, 1412-1416 (1967)

39. Sarwar, G., McDonough, F.E.: Evaluation of protein digestibilitycorrected amino acid score method for assessing protein quality of foods. J. Assoc. Off. Anal. Chem. 73, 347-356 (1989)

40. FAO/WHO F, AOHO: Necessidades de energia y de proteínas. In: Inf. una Reun. Consult. conjunta fao/who/unu Expert. Genebra (1985)

41. Pires, C.V., Oliveira, M.G.D.A., Rosa, J.C., Costa, N.M.B.: Qualidade nutricional e escore químico de aminoácidos de diferentes fontes protéicas. Ciência e Tecnol. Aliment 26, 179-187 (2006). doi:10.1590/S0101-20612006000100029

42. WHO: Protein and amino acid requirements in human nutrition. World Health Organization Technical Report Series 1 (2007)

43. Soccol, C.R., Vandenberghe, L.P.S.: Overview of applied solidstate fermentation in Brazil. Biochem. Eng. J. 13, 205-218 (2003). doi:10.1016/S1369-703X(02)00133-X

44. Uenojo, M., Pastore, G.M.: Pectinases: aplicações industriais e perspectivas. Quim. Nova 30, 388 (2007)

45. Pinto, G.A.S., Brito, E.S., Andrade, A.M.R., Fraga, S.L.P., Teixeira, R.B.: Fermentação em Estado Sólido: Uma alternativa para o Aproveitamento e Valorização de Resíduos Agroindustriais Tropicais. Fortaleza (2005)

46. Sargantanis, J., Karim, M.N., Murphy, V.G., et al.: Effect of operating conditions on solid substrate fermentation. Biotechnol. Bioeng. 42, 149-158 (1993)

47. Campos, A.R.N., Santana, R.A.C., Dantas, J.P., et al.: Enriquecimento protéico do bagaço do pedúnculo de caju por cultivo semisólido. Revista de Biologia e Ciências da Terra 5, 1-11 (2005)

48. Dulf, F.V., Vodnar, D.C., Socaciu, C.: Effects of solid-state fermentation with two filamentous fungi on the total phenolic contents, flavonoids, antioxidant activities and lipid fractions of plum fruit (Prunus domestica L.) by-products. Food Chem. 209, 27-36 (2016). doi:10.1016/j.foodchem.2016.04.016

49. Munhoz, J.: Aplicação de fungos comestíveis (Pleurotus spp.) na degradação de resíduos agroindustriais com avaliação na degradabilidade ruminal em bubalinos. USP_-Universidade de São Paulo (2003) 
50. Darwish, G.A.M.A., Bakr, A.A., Abdallah, M.M.F.: Nutritional value upgrading of maize stalk by using Pleurotus ostreatus and Saccharomyces cerevisiae in solid state fermentation. Ann. Agric. Sci. 57, 47-51 (2012)

51. Suhet, M.I., Fioreze, R.: Semi-solid fermentation of the pineapple residue. Tecnol. Ciência Agropecuária 5, 47-52 (2011)

52. Joint W.H.O.: Protein and amino acid requirements in human nutrition. World Health Organization technical report series 935, pp. 1-265 (2007)

53. Morales, E. M.: Viabilidade de obtenção de alimento funcional a base de mesocarpo de babaçu (Orbignya sp.) e folhas de mandioca (Manihot esculenta) mediante fermentação por Rhizopus microsporus var. oligosporus. Universidade Estadual Paulista Julio de Mesquita Filho-UNESP-Rio Claro (2012)

54. Oke, O.L.: Toxicity of cyanogenic glycosides. Food Chem. 6, 97-109 (1980)

55. Ene-Obong, H.N., Obizoba, I.C.: Effect of domestic processing on the cooking time, nutrients, antinutrients and in vitro Protein digestibility of the African yambean (Sphenostylis stenocarpa). Plant Foods Hum. Nutr. 49, 43-52 (1996)
56. Santana, L.F.R., Costa, N.M.B., Oliveira, M.D.A., Gomes, M.R.A.: Valor nutritivo e fatores antinutricionais de multimisturas utilizadas como alternativa alimentar. Braz. J. Food Technol. 3(45), 129-135 (2000)

57. Câmara, F.S., Madruga, M.S.: Cyanic acid, phytic acid, total tannin and aflatoxin contents of a Brazilian (Natal) multimistura preparation. Rev. Nutr. 14, 33-36 (2001). doi:10.1590/S141552732001000100005

58. Cereda, M.P., Cereda, M.P., Vilpoux, O.F.: Processamento da mandioca como mecanismo de detoxificação. Tecnol usos e potencialidades tuberosas amiláceas Lat Am São Paulo Fundação Cargill, pp. 47-80 (2002)

59. Helbig, E., Buchweitz, M.R.D., Gigante, D.P.: Analysis of hydrogen cyanide and phytic acid contents in feeding supplements: Multimixture. Rev. Nutr. 21, 323-328 (2008). doi:10. 1590/S1415-52732008000300007

60. Reis, D.D.: Estudo da composição nutricional e dos coeficientes de digestibilidade da farinha amilácea fina do babaçu determinada com suínos nas fases de crescimento e terminação. Universidade Federal de Tocantins (2009) 